TOWARD THE DEVELOPMENT OF A SOFT X-RAY REFLECTION IMAGING MICROSCOPE IN THE SCHWARZSCHILD CONFIGURATION USING A SOFT X-RAY LASER AT $18.2 \mathrm{~nm}$.

BY

D. DICICCO, D. KIM, R. ROSSER AND S. SUCKEWER

December 1991
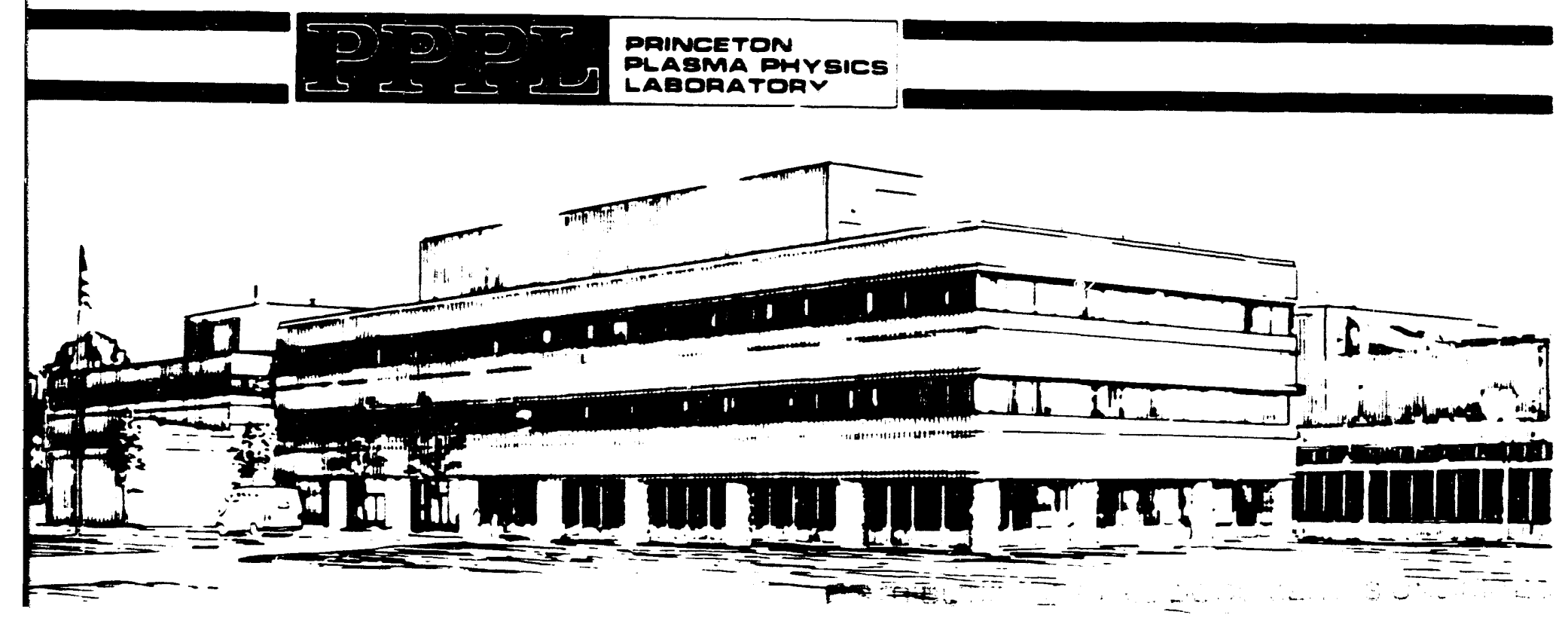


\section{NOTICE}

This report was prepared as an account of work sponsored by an agency of the United States Governmert. Neither the United States Government nor any agency thereof, nor any of their employees, makes any warranty, express or implied, or assumes any legal liability or responsibility for the accuracy, completeness, or usefulness of any information, apparatus, product, or process disclosed, or represents that its use would not infringe privately owned rights. Reference herein to any specific commercial produce, process, or service by trade name, trademark, manufacturer, or otherwise, does not necessarily constitute or imply its endorsement, recommendation, or favoring by the United States Government or any agency thereof. The views and opinions of authors expressed herein do not necessarily state or reflect those of the United States Government or any agency thereof.

\section{NOTICE}

This report has been reproduced directly from the best available copy.

Available to DOE and DOE contractors from the:

Office of Scientific and Technical Information

P.O. Box 62

Oak Ridge, TN 37831 ;

Prices available from (615) 576-8401.

Available to the public from the:

National Technical Information Service

U.S. Department of Commerce

5285 Port Royal Road

Springfield, Virginia 22161

$703-487-4650$ 


\title{
Toward the Development of a Soft X-ray Reflection Imaging Microscope in the Schwarzschild Configuration Using a Soft X-ray Laser at $18.2 \mathrm{~nm}$.
}

\author{
D. Dicicco ${ }^{\dagger}$, D. Kim, R. Rosser ${ }^{\dagger}$ and S. Suckewer \\ Princeton Plasma Physics Laboratory and \\ Department of Mechanical and Aerospace Engineering, \\ Princeton University, Princeton, NJ 08543
}

\begin{abstract}
We present the recent results obtained from a soft $X$-ray reflection imaging microscope in the Schwarzschild configuration. The microscope demonstrated a spatial resolution of $0.7 \mu \mathrm{m}$ with a magnification of 16 at $18.2 \mathrm{~nm}$. The soft $X$-ray laser at 18.2 $\mathrm{nm}$ was used as an X-ray source. Mo/Si multilayers were coated on the Schwarzschild optics and the normal incidence reflectivity at $18.2 \mathrm{~nm}$ per surface was measured to bi $20 \%$.
\end{abstract}


During the last decade a revolution has occurred in X-ray technology; both in sources and optics. The advent of X-ray lasers ${ }^{1,2}$ and synchrotron insertion devices ${ }^{3}$ has resulted in a remarkable increase in the brightness of laboratory X-ray sources. Significant progress in layered synthetic microstructure technology has opened up the development of normal incidence X-ray optics ${ }^{4}$. These new capabilities allow researchers to devise and develop sophisticated X-ray optical systems ${ }^{5}$ for X-ray microscopy and lithography which would have seemed impossible 10 years ago, one of which is a reflection X-ray microscope.

The main interest in developing a soft $\mathrm{X}$-ray reflection imaging microscope is its potential application to the observation of surfaces (or membranes ) of biological cells and to the high resolution inspection of lithographic products. Optical lithography is already able to produce $0.5 \mu \mathrm{m}$ feature size. Significant efforts are being made in the US and the abroad to produce even smaller feature size for the next generation of integrated circuits. There is an increasing demand for the detection of defects and the inspection of masks with a precision of $0.1 \mu \mathrm{m}$ or better. Although reflectivities of materials in the soft X-ray spectral region are generally low, there is a significant variation in the reflectivity from material to material, allowing high contrast so that a reflection $\mathrm{x}$-ray microscope could image the surfaces of specimens. This principle can aiso be applied to biological cells labeled with high- $Z$ material ( for example, Au ). The sufficient difference in the reflectivity between component elements ( carbon, oxygen, and nitrogen ) of biological cell and labeling materials (e. g. Au ) allows a good contrast image. Recent progress in the Xray technology and the inherent properties of X-ray provide good opportunities to develop a tool to meet such a demand in the near iuture. The success of this experiment offers a path toward the development of a novel microscope offering real time analysis at 25 to 50 $\mathrm{nm}$ resolution with inherent sensitivity to material composition. 
Three optical configurations have been investigated for use in high resolution $x$-ray imaging: Wolter ${ }^{6.7}$, zone-plate ${ }^{8}$, and Schwarzschild configuration ${ }^{9}$. The Schwarzschild configuration is an achromatic system, unlike the zone plate configuration. The Schwarzschild configuration also makes it possible to construct an objective with no spherical aberration, astigmatism or coma. ${ }^{10}$

Several attempts have recently been made to develop X-ray optical system based on the Schwarzschild configuration. ${ }^{11-13}$ These experiments have used synchrotron ${ }^{12}$ or laserproduced plasma ${ }^{11.13}$ as X-ray sources. The Schwarzschild optics have been used in various ways: as imaging optics ${ }^{11}$, as a demagnifier ${ }^{12}$ and as focusing optics ${ }^{13}$. The spatial resolutions of $0.2-0.5 \mu \mathrm{m}$ have been demonstrated.

In this Letter we present the important step toward the development of a soft X-ray reflection imaging microscope using the Schwarzschild configuration. A magneticallyconfined, recombination-pumped C VI 18.2 nm laser developed in 1985 at PPPL ${ }^{14,15}$ was used as an X-ray source for the microscope. The Schwarzschild optics used in our experiments were manufactured by T.R. Optics, Ltd., in England ${ }^{16}$. Surfaces of the optics were polished to the very high surface finish ( $\sim 0.5 \mathrm{~nm}$ rms surface roughness). The Schwarzschild mirror system comprises a concave and a convex mirror. The diameter of the large concave mirror is $66.3 \mathrm{~mm}$ and its radius of curvature is $68.5 \mathrm{~mm}$. The small convex mirror is $14.5 \mathrm{~mm}$ in diameter with the radius of curvature being $23 \mathrm{~mm}$. The Schwarzschild mirror system has a numerical aperture of 0.4 and a focal length of $14 \mathrm{~mm}$. Multilayer coating and the measurement of its reflectivity ${ }^{17}$ were done by the Advanced Optics Group of the Lawrence Livermore National Laboratory. The multilayer coating consists of 15 layer-pairs of molybdenum and silicon layers, whose thicknesses are $\sim 3 \mathrm{~nm}$ and $\sim 9 \mathrm{~nm}$, respectively. Figure 1 shows the measured and calculated reflectivity of the multilayer-coated mirror in the vicinity of $18.2 \mathrm{~nm}$. The calculation of the reflectivity was done using a code developed by Oxford Research Group. ${ }^{18}$ This calculation assumes the abrupt transition and perfect smoothness between Mo and Si layers. Although this code is 
capable of modeling interdiffusion between layers, this option was not used because of the lack of experimental data. The important conclusions are the matching of the shape of reflectivity curves; especially, the location of the peak, B, and the side lobes, A and C, and other structures. The discrepancy of the factor of 2 in magnitude between the measured and calculated reflectivity is assumed to be due to scattering due to surface roughness of the optics and to interlayer diffusion in the multilayer coating.

The Schwarzschild mirror system was used in two sets of experiments. The purpose of the frst set of experiments was to test the Schwarzschild optics in the transmission imaging configuration; on the other hand, the goal of the second set of experiments was to demonstrate the principle of a soft $\mathrm{X}$-ray reflection microscope. Figure 2 shows the experimental set-up in which transmission imaging experiments were performed. The $18.2 \mathrm{~nm}$ soft $\mathrm{X}$-ray laser has a rather large divergence $(5-10 \mathrm{mrad})^{15}$ due to the single-pass amplification ( It does not have cavity mirrors around the gain medium). A one-to-one transfer ellipsoidal grazing incidence mirror was used to collect and focus the $18.2 \mathrm{~nm}$ radiation onto a Cu TEM (Transmission Electron Microscope) \# 400 grid. The transfer mirror is made from Al substrate, figured to a ellipsoidal shape with a diamond tool, plated with nickel and coated with rhodium. The mirror assembly has four translators for the precise control of the mirror position. The numerical aperture of this ellipsoidal mirror is 0.1 . Since the numerical aperture of the central obstruction of the Schwarzschild mirror system used in this experiment is larger ( 0.17 ) than that of the ellipsoidal mirror, the Schwarzschild mirror system was tilted at $15^{\circ}$ off axis. An $80 \mathrm{~nm}$ thick Al filter, with a coating of $10 \mathrm{~nm}$ of carbon film, was placed before the Cu TEM \#400 grid ( period is $63 \mu \mathrm{m}$ ) to block out VUV, UV and visible light. The transmission of the filter is about $56 \%$ at $18.2 \mathrm{~nm}$. The TEM grid was illuminated by light passing through the filter and imaged by the Mo/Si multilayer-coated Schwarzschild mirror system with a magnification of 22 onto Kodak 101-07 X-ray film. Figure 3 show's the recorded picture. After we obtained the image as shown in Fig. 3, we intentionally reversed an X-ray film to 
double check that the exposure was done by X-rays. If there were any longer wavelength light (especially, visible light) passing through the Al filter in front of the TEM grid, it would expose a reversed X-ray film ( The film is thick so that all X-rays would be absorbed in the backside of the film before it gets the emulsion surface). We did not observe any exposure with a film being reversed. Due to the much lower beam energy of the $18.2 \mathrm{~nm}$ soft $\mathrm{X}$-ray laser than at its best performance, multiple shots (8) were required to record a picture with a good contrast as shown in Fig. 3. The specimen field of view is $1.3 \mathrm{~mm}$ by $0.7 \mathrm{~mm}$. The image was scanned with a densitometer to produce the race shown in Fig. 4. The spatial resolution was found to be $-0.7 \mu \mathrm{m}$ at $25-75 \%$ contrast.

Once the Schwarzschild optics were verified to function properly, the optics were rearranged in the reflection imaging configuration as shown in Fig. 5. The $18.2 \mathrm{~nm}$ laser beam was aligned to a reflection object which was constructed by evaporating gold onto a polished glass surface through a TEM \#200 grid. The angle of incidence of the $18.2 \mathrm{~nm}$ laser beam to the reflection object was limited by our vacuum chamber adjustment to $70^{\circ}$ ( or the angle of $20^{\circ}$ between the reflection surface and the incident beam ), at which the reflectivities of Au and a glass are calculated to be $\sim 35 \%$ and $\sim 1.5 \%$, respectively. The difference in the reflectivity at this angle between gold and glass is large enough to produce a good contrast image. The image of the reflection object recorded on Kodak 101-07 X-ray film is shown in Fig. 6. The dark lines represent the glass part of the reflection object, while the white areas represent the gold part.

In conclusion, we have verified the operation of the Schwarzschild optics using an 18.2 nm laser. The same optics were used to demonstrate the feasibility of a soft X-ray reflection microscope which relies on the difference in reflectivity from material surfaces for contrast. Further efforts are already underway toward increasing the magnification from 16 to 100 and replacing $X$-ray films as a recording medium with a CCD detector. 
We greatly acknowledge N. Ceglio and his Advanced Optics Group at Lawrence Livermore National Laboratory for providing a multilaye: coating on the Schwarzschild optics. We also thark $N$. Tkach for his technical support.

This work was supported by Department of Energy's Small Business Research Innovative Phase I Grant; \#DE-FG05-90ER80967.

$\div$ Princeton X-ray Laser, Inc. 1-H Deerpark Dr., Monmouth Junction, NJ 08852 


\section{References}

1. C. H. Skinner, Phys. Fluids: to be published in Aug.,1991; PPPL report \#2741, 1991.

2. R. C. Elton, X-ray Lasers, Academic Press, Boston (1990).

3. P. Elleaume, Synchrotron Radiation News 1, 18 (1988).

4. T. W. Barbee, Jr., Optical Engineering 25, 898 (1986).

5. N. M. Ceglio, Journal of X-ray Science and Technology 1, 7 (1989); M. R. Howells, J. Kirz, and D. Sayre, Scientific American, 88 (Feb., 1991).

6. A. Frank and B. Gale, in Applications of Thin-Film Multilayered Structures to Figured X-ray Optics, G. F. Marshall, Ed., Proc. SPIE 563, 81 (1985).

7. R. H. Price, in Low Energy X-ray Diagnostics-1981, D.T. Attwood and B. L. Henke, eds., Proc. AIP 75, 189 (1981).

8. P. Guttman, in X-ray Microscopy, G. Schmahl and D. Rudolph, eds. (SpringerVerlag, Berlin, 1984), p. 75.

9. B. Lai and F. Cerrina, in Applications of Thin-Fijm Multilayered Structures to Figured X-ray Optics, G. F. Marshall, Ed., Proc. SPIE 563, 174 (1985).

10. R. Kingslake, Lens Design Fundamentals, Academic Press, p. 331 (1978).

11. M. Kado, K. A. Tanaka, R. Kodama, T. Yamanaka, and S. Nakai, Opt. Lett. 16, 109 (1991).

12. D.W. Berreman, J. E. Bjorkholm, L. Eichner, R.R. Freeman, T.E. Jewell, W. M. Mansfield, A. A. MacDowell, M. L. O'Malley, E. L. Raab, W. T. Silfvast, L. H. Szeto, D. M. Tennant, W. K. Waskiewicz, D. L. White, D. L. Windt, O. R. Wood II, and J. H. Bruning, Opt. Lett. 15, 529 (1990).

13. J. A. Trail and R. L. Byer, Opt. Lett. 14, 539 (1989). 
14. S. Suckewer, C. H. Skinner, H. Milchberg, C. Keane, and D. Voorhees, Phys. Rev. Lett. 55, 1753 (1985).

15. S. Suckewer, C.H. Skinner, D. Kim, E. Valeo, D. Voorhees and A. Wouters, Phys. Rev. Lett. 57, 1004 (1986).

16. T. R. Optics, Ltd.,16 Queen's Rd, Brentwood, Essex, CM144HE, England

17. N. M. Ceglio, private communication

18. Oxford Research Group, 5737 Clinton Ave., Richmon, CA 94805. 


\section{Figure Captions}

Fig. 1. (a) The measured reflectivity of the Mo/Si multilayer-coated mirror in the vicinity of $18.2 \mathrm{~nm}$. The reflectivity of the mirror is about $20 \%$ at $18.2 \mathrm{~nm}$. (b) The calculated reflectivity of the mirror. The abrupt transition and perfect smoothness between Mo and Si layers are assumed in this calculation. The discrepancy between the measured and calculated reflectivity may be attributed to the interdiffusion of one layer into another and the possible surface roughness in the interface

Fig. 2. The experimental layout in the transmission imaging configuration.

The Schwarzschild mirror system was tilted at $15^{\circ}$ off axis because the numerical aperture of the focusing ellipsoidal mirror is smaller than that of the central obstruction of the Schwarzschild mirror system.

Fig. 3. The picture of image of a TEM \#400 Cu grid with a magnification of 22 recorded on Kodak 101-07 X-ray film in the transmission imaging configuration.

Fig. 4. The densitometer scan of the image shown in Fig. 3. The spatial resolution of 0.7 $\mu \mathrm{m}$ is demonstrated at $25-75 \%$ contrast.

Fig. 5. The experimental layout in the reflection imaging configuration. The angle between the reflection surface and the incident beam is set to be $20^{\circ}$. The Schwarzschild mirror system was tilted at $15^{\circ}$ off axis.

Fig. 6. The picture of image of a reflection object in the reflection imaging configuration. The reflection object was constructed by evaporating gold onto a polished glass surface through a TEM \#200 grid. The image was recorded on Kodak 101-07 Xray film. The dark lines represent the glass part of the reflection object, while the white areas represent the gold part. The magnification was 16 in this case. 

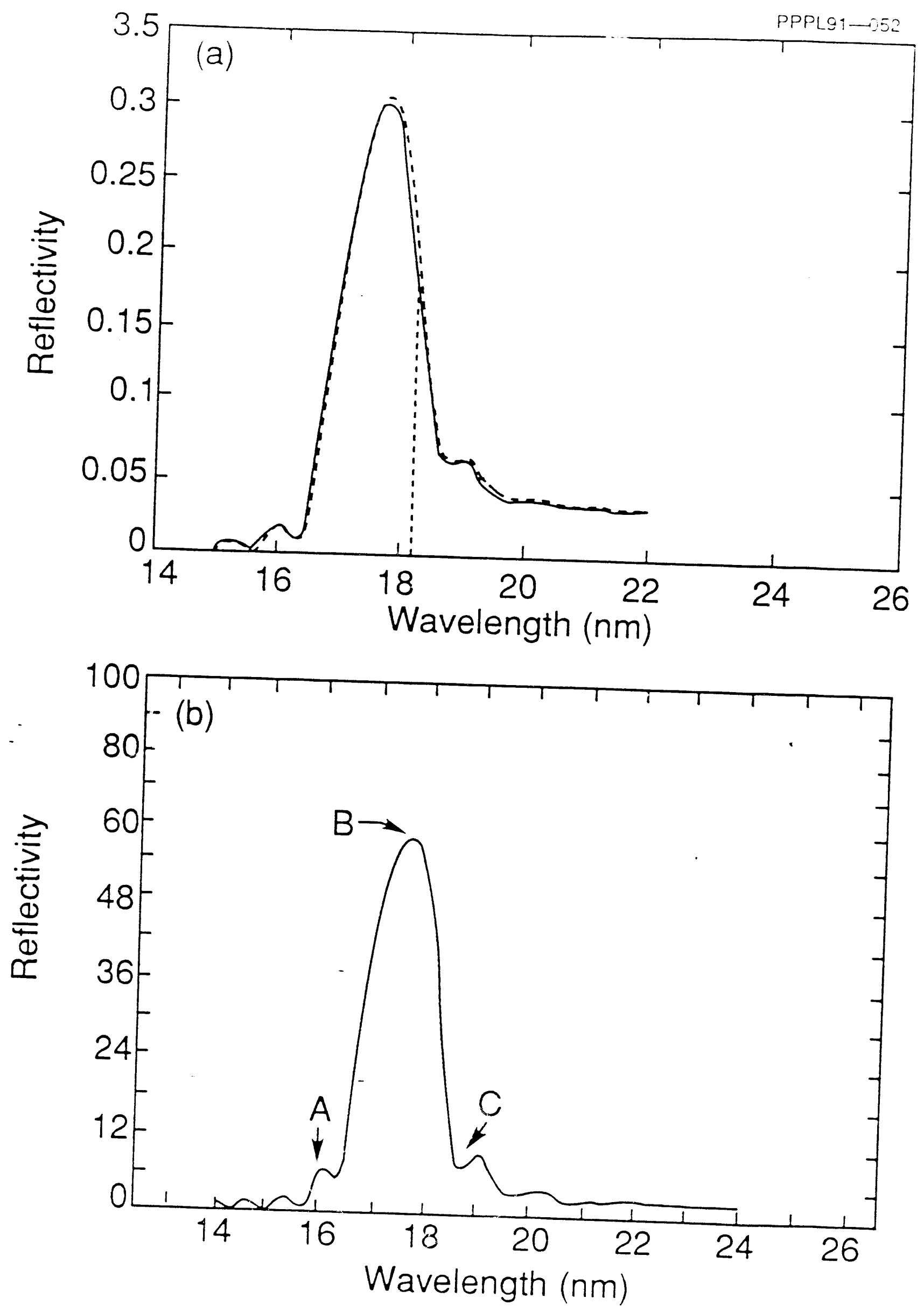

Fig. 1. 


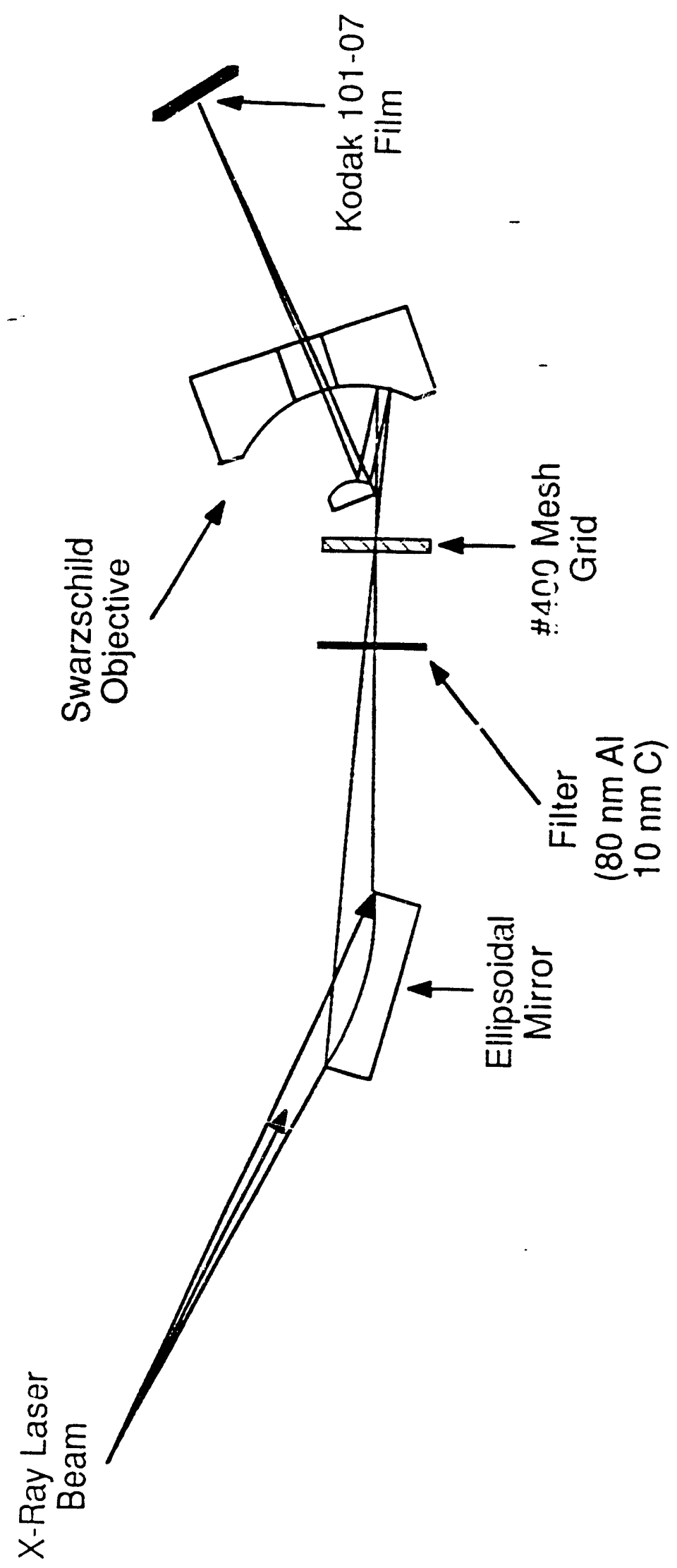

훈 


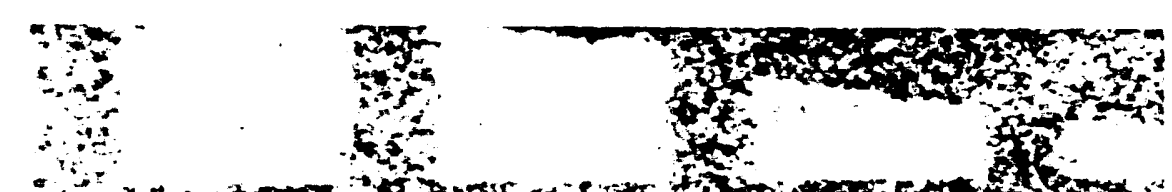

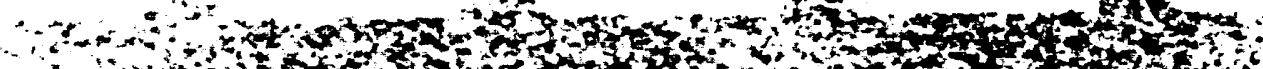

$\therefore$ n

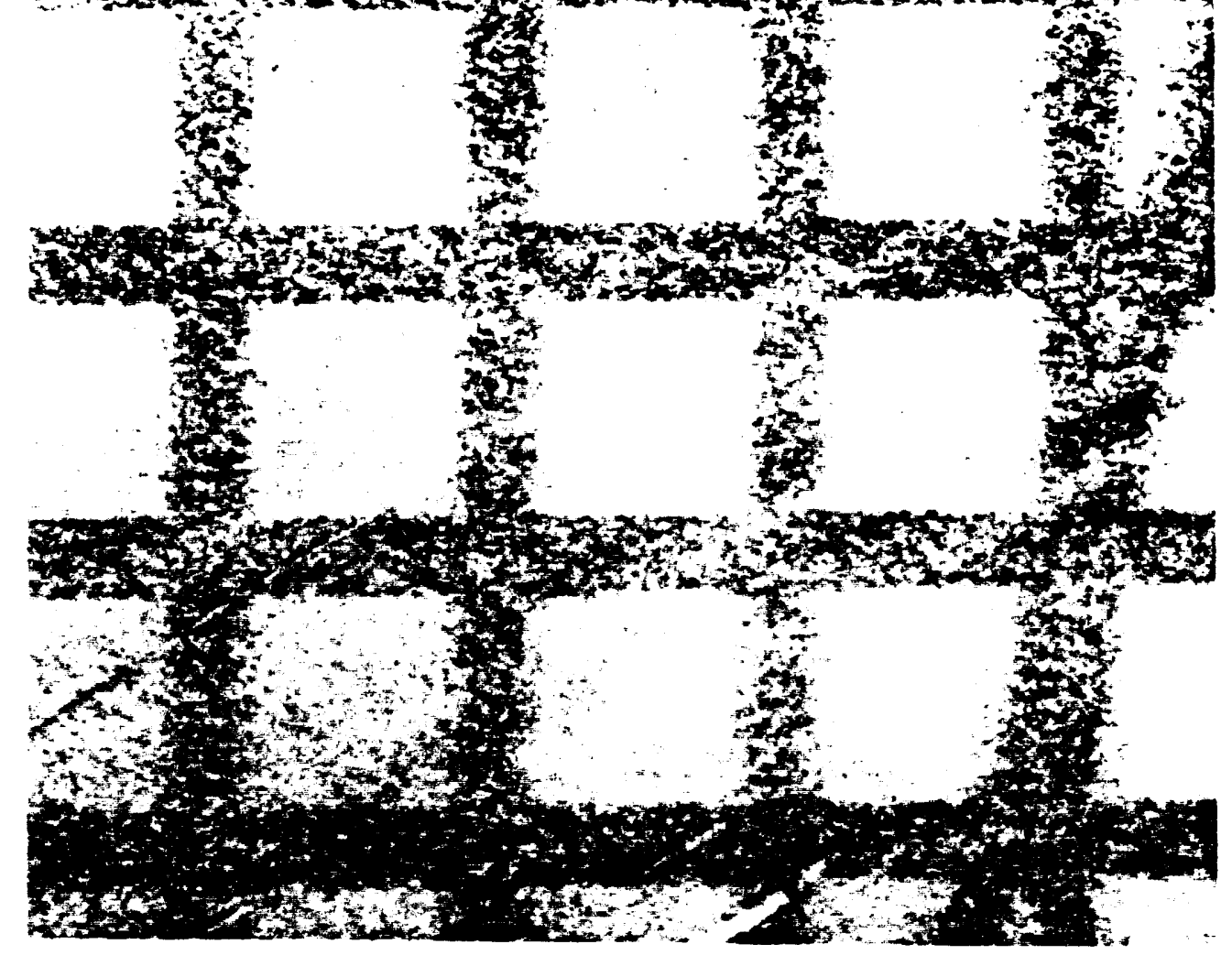

Fig. 3 


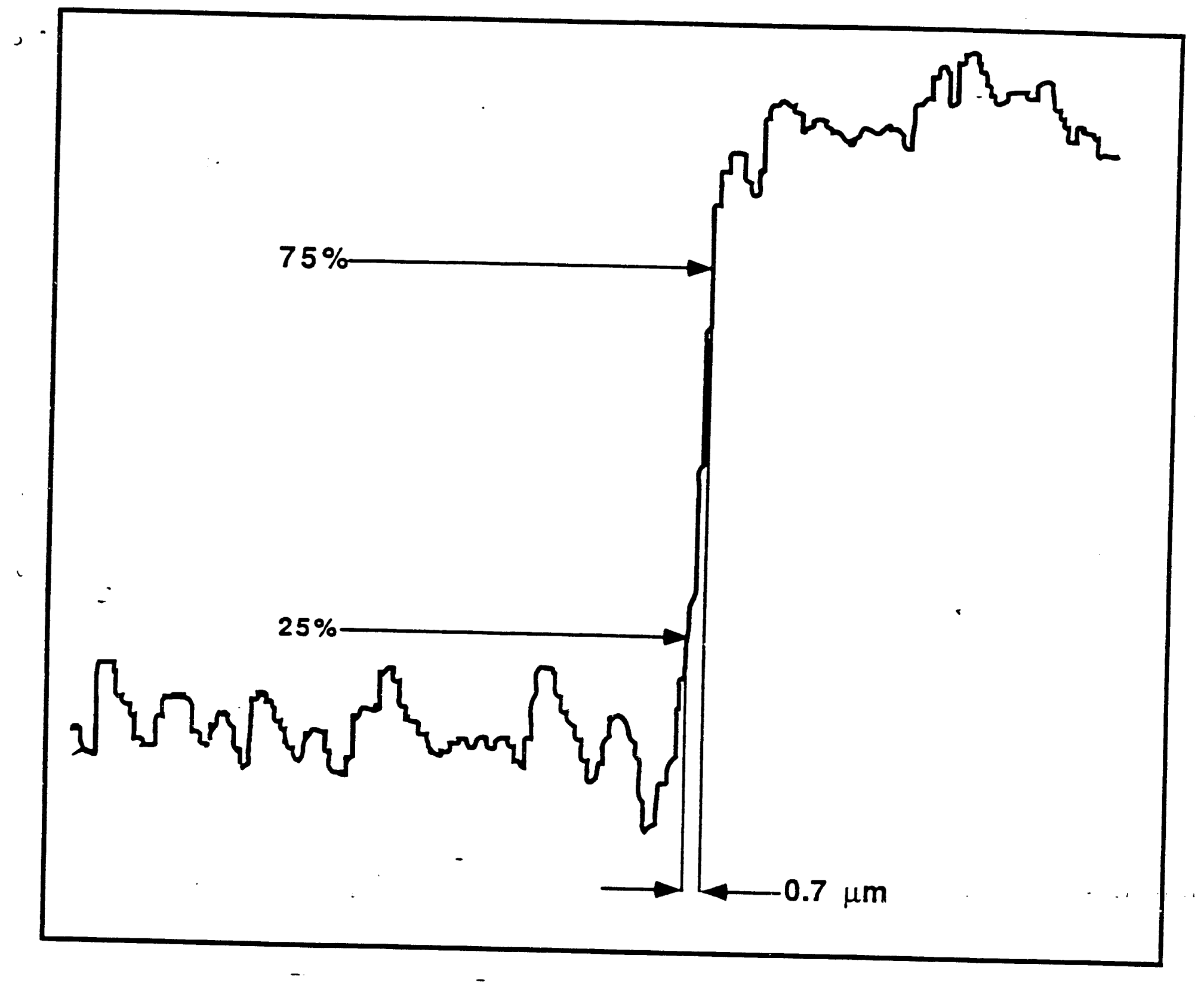

Fig. 4. 


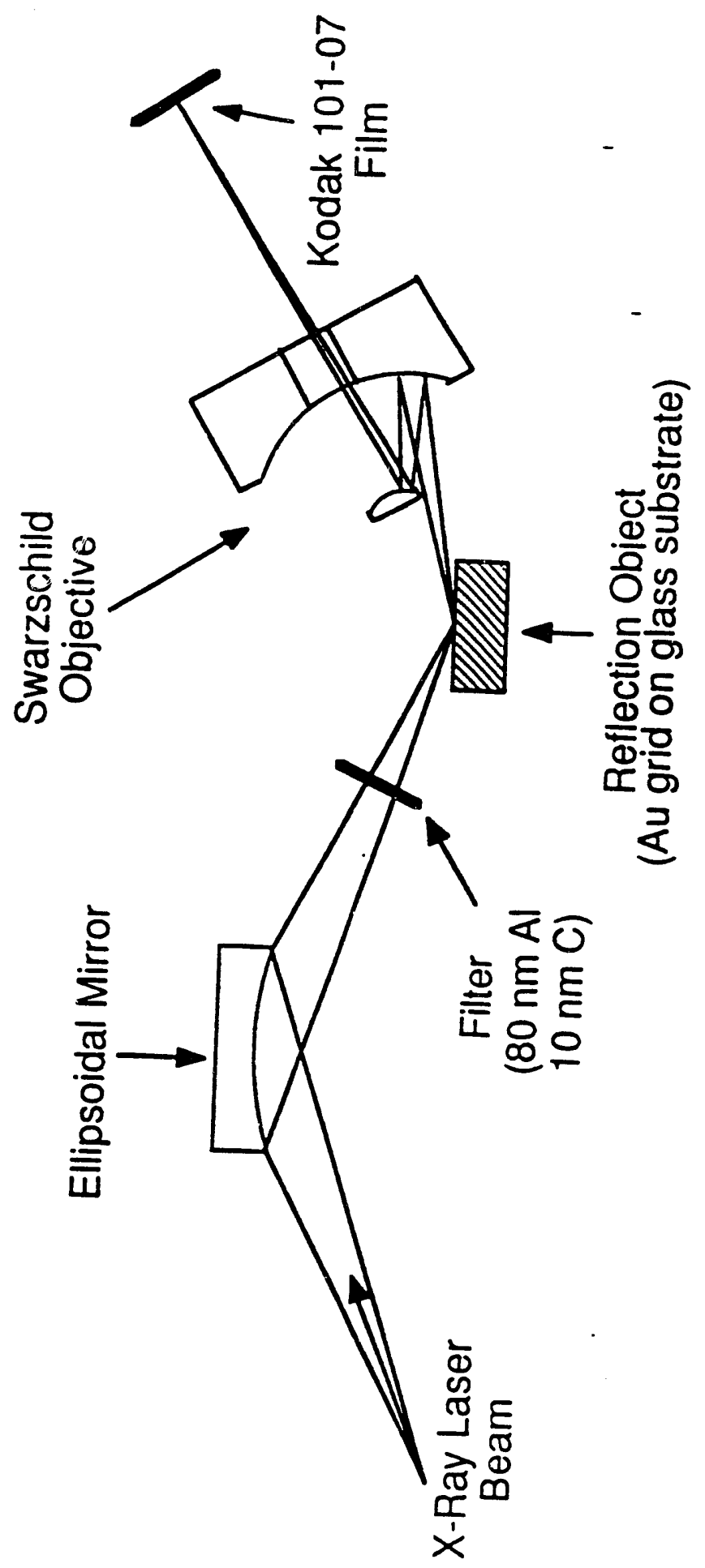




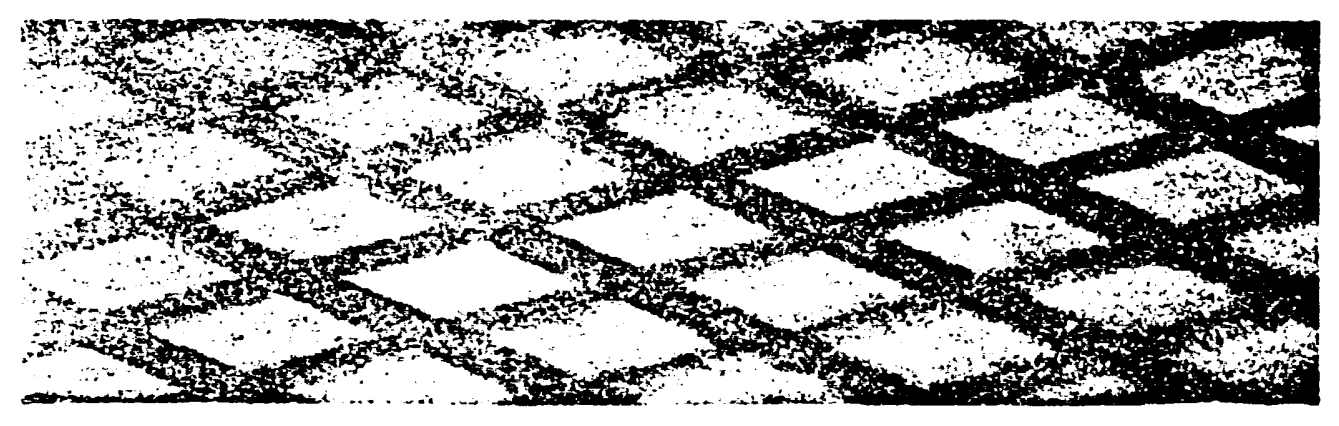

Fig. 6 
Dr. F. Paoloni, Univ. of Wollongong. AUSTRALIA

Prot. M.H. Brennan, Univ. of Sydnoy, AUSTRALIA

Plasma Research Lab., Australian Nat. Univ., AUSTRALIA

Prof. I.R. Jones. Flinders Univ. AUSTRALIA

Prof. F. Cap, Inst. for Theoretical Physics, AUSTRIA

Prot. M. Heindler, Institut for Theoretisctie Physik, AUSTRIA

Prot. M. Goossens. Astronomisch Insutuut, BELGIUM

Ecole Royale Militaire, Lab. de Phy. Plasmas, BELGIUM

Commission-European, DG. XII-Fusion Prog., BELGIUM

Prof. R. Bouciaie, Rijksuniversitsit Gent, BELGIUM

Dr. P.H. Sakanaka, Instituto Fisica, BRAZIL

Instituto Do Pesquisas Espociais-INPE, BRAZIL

Documents Office, Alomic Energy of Canada Lid., CANADA

Dr. M.P. Bechynski, MPB Technologies, Inc., CANADA

Dr. H.M. Skarsgard, Univ. of Saskatchewan, CANADA

Prot. J. Teichmenn, Univ. of Montreal, CANADA

Prof. S.R. Sreonivasan. Univ. of Calgary, CANADA

Prof. T.W. Johnston, INRS-Energie, CANADA

Dr. R. Bolton. Contre canadien de fusion magnétique, CANADA

Dr. C.R. James.. Univ. of Alberta, CANADA

Dr. P. Lukac, Komenskeho Universzita, CZECHOSLOVAKIA

The Librarian, Cutham Laboratory, ENGLAND

Library, R61, Rutherford Appleton Laboratory, ENGLAND

Mrs. S.A. Hutchinson, JET Library, ENGLANCI

P. Mahonen, Univ. of Helsinkj, FINLAND

C. Moutter, Lab. de Physique des Milieux lonisés, FRANCE

J. Radet, CEN/CADARACHE - Bat 506, FRANCE

Ms. C. Rinni, Univ. of loannina, GREECE

Dr. T. Mual, Academy Bibliographic Ser., HONG KONG

Proprint Library. Hungarian Acadomy of Sci., HUNGARY

Dr. B. Das Gupta. Saha inst. of Nudear Physics, INDIA

Dr. P. Kaw, Inst for Plasma Research, INDIA

Dr. P. Rosenau, Israel inst of Tectinology. ISRAEL

Librarian, Intermational Center for Theo Physics, ITALY

Miss C. De Palo, Associazione EURATOMENEA, ITALY

Dr G. Grosso, Istibuto di Fisica del Plasma, ITALY

Dr. H. Yamato, Toshiba Res \& Dovel Center, JAPAN

Prof. I. Kawakami, Atomic Energy Res. Inst., JAPAN

Prof. K. Nishikawa, Hiroshima Univ., JAPAN
Director, Japan Atomic Energy Research Inst., JAPAN

Prof. S. Itoh. Kyushu Univ., JAPAN

Data and Planning Center. Nagoya Univ., JAPAN

Prof. S. Tanaka. Kyoto Univ., JAPAN

Library, Kyoto Univ., JAPAN

Prof. N. Inove. Univ. of Tokyo. JAPAN

S. Mori, Technical Advisor, JAERI, JAPAN

O. Mitara, Kumamoto Inst. of Tochnology. JAPAN

H. Jeong. Korea Advanced Energy Research Inst., KOREA

Prof. D.I. Choi. The Korea Adv. Inst. of Sai. \& Tech., KOREA

Prof. B.S. Liby, Univ. of Waikato, NEW ZEALAND

Inst. of Plasma Physics, PEOPLE'S REPUBLIC OF CHINA

Librarian, Inst of Physics, PEOPLE'S REPUBLC OF CHINA

Library, Tsinghua Univ., PEOPLE'S REPUBLIC OF CHINA

Z. Li, S.W. Inst Physics, PEOPLE'S REPLBLIC OF CHINA

Prof. J.A.C. Cabra, Instituto Superior Tecnico, PORTUGAL

Dr. O. Petrus, Al I Cuza Univ., Romania

Dr. J. de Villiers, Fusion Sudies, AEC, S. AFRICA

Prof. M.A. Hellberg, Univ. of Nata. S. AFRICA

C.I.E.MA.T, Fusion Division Library, SPAIN

Dr. L Sionfio, Univ. of UMEA, SWEDEN

Libray, Royal Inst of Tectnology. SWEDEN

Prof. H. Witholmson, Chalmers Univ. of Tech., SWEDEN

Contre Phys. Des Plasmas, Ecole Potytoch, SWITZERLAND

Bibliotheok, Inst. Voor Plasma-fysica, THE NETHERLANDS

M. Durgut, Vice Chaiman, Middle East Tech. Univ., TURKEY

Dr. D.D. Ryutov, Siberian Branch of ACademy of Sai., USSR

Dr. G.A. Eliseev, Kurchatov inst, USSR

Libranian. The Ukr.SSR Academy of Scionces, USSR

Dr. LM. Kourizhnykh, Inst. of Genera Physics, USSR

Kemforschungsanlage GmbH, Zentrabibtiothek, W. GERMANY

Bibliothek, Inst. Für Plasmaforsctung, W. GERMANY

Prof. K. Schinder, Ruhr-Universitat Bochum, W. GERMANY

Dr. F. Wagner, (ASDEX), Max-Planck-Institut, W. GERMANY

Librarian, Max-Planck-Institut, W. GERMANY

Prot. R.K. Janev, Inst. of Physics, YUGOSLAVIA 

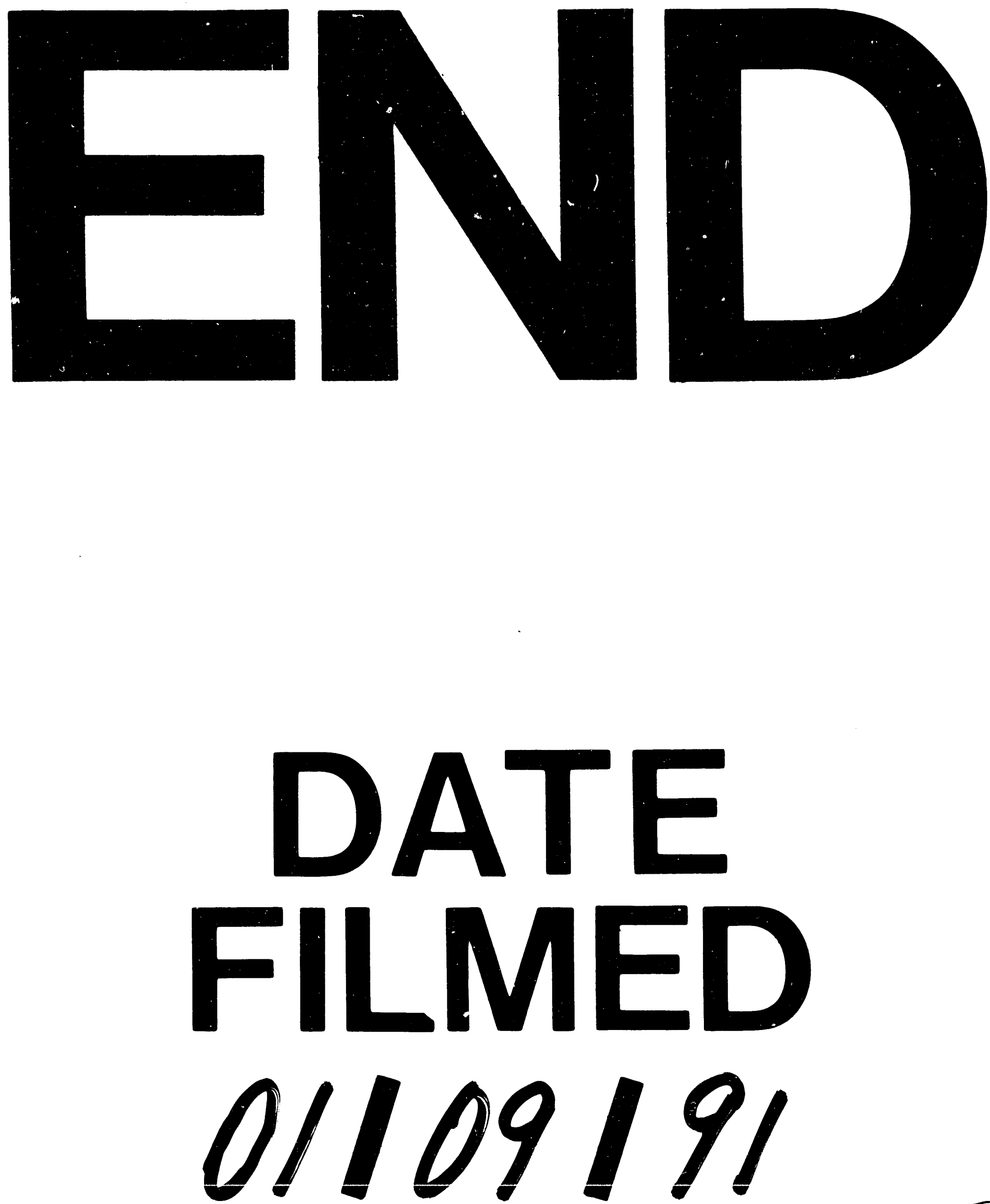
